\title{
Wind forcing of salinity anomalies in the Denmark Strait overflow
}

\author{
S. Hall ${ }^{1,2}$, S. R. Dye ${ }^{2}$, K. J. Heywood ${ }^{1}$, and M. R. Wadley $^{3}$ \\ ${ }^{1}$ School of Environmental Sciences, University of East Anglia, Norwich, UK \\ ${ }^{2}$ Centre for Environment, Fisheries and Aquaculture Science (Cefas), Lowestoft, UK \\ ${ }^{3}$ School of Mathematics, University of East Anglia, Norwich, UK
}

Received: 20 May 2011 - Published in Ocean Sci. Discuss.: 21 June 2011

Revised: 14 October 2011 - Accepted: 14 November 2011 - Published: 30 November 2011

\begin{abstract}
The overflow of dense water from the Nordic Seas to the North Atlantic through Denmark Strait is an important part of the global thermohaline circulation. The salinity of the overflow plume has been measured by an array of current meters across the continental slope off the coast of Angmagssalik, southeast Greenland since September 1998. During 2004 the salinity of the overflow plume changed dramatically; the entire width of the array $(70 \mathrm{~km})$ freshened between January 2004 and July 2004, with a significant negative salinity anomaly of about 0.06 in May. The event in May represents a fresh anomaly of over 3 standard deviations from the mean since recording began in 1998. The OCCAM $1 / 12^{\circ}$ Ocean General Circulation Model not only reproduces the 2004 freshening event $(r=0.96, p<0.01)$, but also correlates well with salinity observations over a previous 6 year period ( $r=0.54, p<0.01$ ), despite the inevitable limitations of a z-coordinate model in representing the mixing processes at and downstream of the Denmark Strait sill. Consequently the physical processes causing the 2004 anomaly and prior variability in salinity are investigated using the model output. Our results reject the hypotheses that the anomaly is caused by processes occurring between the overflow sill and the moorings, or by an increase in upstream net freshwater input. Instead, we show that the 2004 salinity anomaly is caused by an increase in volume flux of low salinity water, with a potential density greater than $27.60 \mathrm{~kg} \mathrm{~m}^{-3}$, flowing towards the Denmark Strait sill in the East Greenland Current. This is caused by an increase in southward wind stress upstream of the sill at around $75^{\circ} \mathrm{N} 20^{\circ} \mathrm{W}$ four and a half months earlier, and an associated strengthening of the East Greenland Current.
\end{abstract}

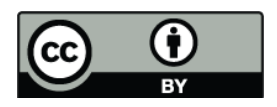

Correspondence to: K. J. Heywood (k.heywood@uea.ac.uk)

\section{Introduction}

The overflow of cold, dense water from the Nordic Seas to the Atlantic Ocean across the Greenland-Scotland Ridge is an important component of the global thermohaline circulation. The total overflow is about $6 \mathrm{~Sv}\left(1 \mathrm{~Sv}=10^{6} \mathrm{~m}^{3} \mathrm{~s}^{-1}\right)$, with roughly half of this passing through Denmark Strait, and the other half passing east of Iceland mainly through the Faroe Bank Channel (Dickson and Brown, 1994; Hansen and Østerhus, 2000). Intense mixing immediately downstream of the Denmark Strait overflow sill (Fig. 1) induces strong entrainment of ambient Atlantic waters into the overflow plume (Voet and Quadfasel, 2010), that flows southwards along the Greenland continental slope into the deep North Atlantic as Denmark Strait Overflow Water (DSOW). Here we use the DSOW definition of Dickson et al. (2008) as water with a potential density $\left(\sigma_{\theta}\right)$ greater than 27.85 (values of $\sigma_{\theta}$ will be quoted without units here). This system of overflow and entrainment is the main contributor to North Atlantic Deep Water (NADW), the deep limb of the global thermohaline circulation (Dickson and Brown, 1994). In addition to DSOW, the surface waters of the East Greenland Current (EGC) also flow south through Denmark Strait, and Pickart et al. (2005) identified a separate southward current formed from dense water cascading over the East Greenland shelf edge south of the sill, known as the East Greenland Spill Jet. The purpose of this paper is to establish the cause of observed salinity anomalies in DSOW.

The source of DSOW is still an open question, but the EGC, and currents originating in the Iceland Sea (the North Icelandic Jet), are widely recognised as the main pathways for different DSOW sources to reach the overflow sill (Rudels et al., 2002; Jónsson and Valdimarrson, 2004; Köhl, 2010) (Fig. 1). Any changes to the proportion of each constituent source water mass making up the total overflow just north of the sill, or a modification to the salinity characteristics of those water masses, have the potential to impact

Published by Copernicus Publications on behalf of the European Geosciences Union. 


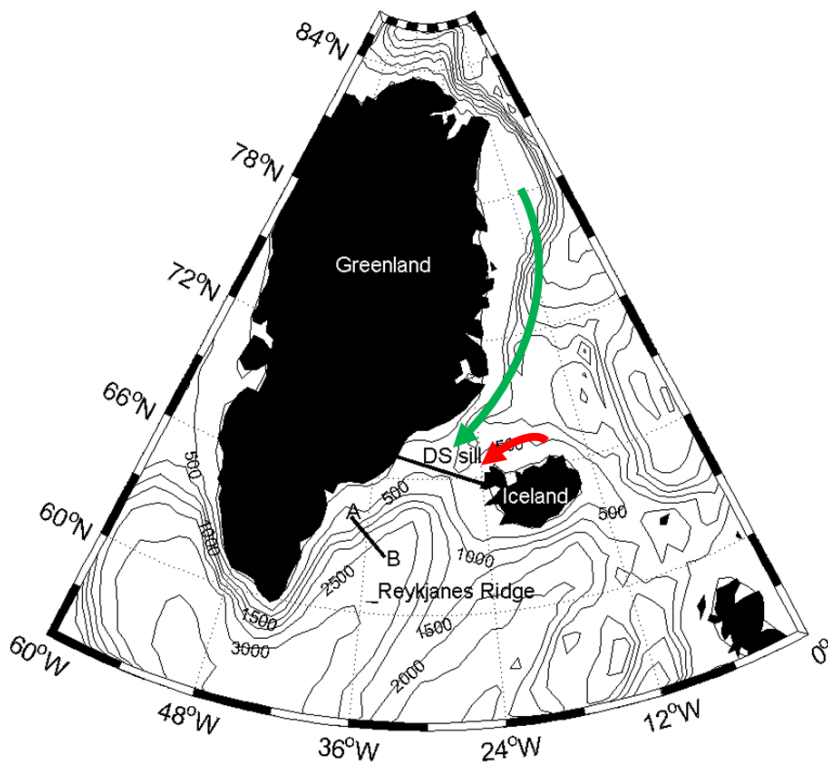

Fig. 1. Map showing the Denmark Strait overflow sill (DS sill) and the Angmagssalik mooring array (Section AB). All isobaths are in metres. DSOW source pathways: EGC (green), North Icelandic Jet (red) (Jónsson and Valdimarsson, 2004).

the salinity of the deep overflow. In addition, entrainment downstream of the sill can modify properties of DSOW. A long-term freshening trend and interannual fresh anomalies at the overflow have previously been attributed to an increase in freshwater input to the Nordic Seas from higher net precipitation, sea-ice melt and glacial run-off (Dickson et al., 2002; Curry et al., 2003; Peterson et al., 2006). However, most studies so far have implicated changes to the proportions of each water mass comprising the overflow as the main cause of observed salinity anomalies downstream of Denmark Strait, driven by changes in the local wind forcing. Rudels et al. (2002) reported that in 1990 increased winddriven mixing resulted in a larger volume flux from the Iceland Sea, causing fresher and colder DSOW. They argue that it is the final mixing just north of Denmark Strait that sets the DSOW characteristics by changing the contributions from the different water masses involved in the DSOW formation. By comparing water masses derived from hydrographic observations upstream of Denmark Strait, Rudels et al. (2003) show that on time scales from months to years, wind forcing variability determines whether the DSOW originates predominantly from either the Iceland Sea or the EGC.

More recently, Holfort and Albrecht (2007) argued that salinity anomalies in the overflow are driven by changes in the local wind forcing, based upon significant correlations between DSOW salinity and the wind stress west and north of Iceland. They speculated that stronger southward winds could result in a greater volume of low salinity water flowing from the north towards Denmark Strait in the EGC, with a lesser volume of higher salinity Recirculating Atlantic Water (RAW) present immediately upstream of the sill.

Our study identifies and assesses several possible mechanisms responsible for salinity anomalies in the overflow plume downstream of the sill, and investigates the likely contribution from each mechanism. Hypotheses are formulated and tested using a combination of observational data, reanalysis, and an eddy-resolving Ocean General Circulation Model (OGCM). Section 2 provides an overview of the observational data used for this study and states the hypotheses to be tested. Section 3 introduces the OGCM and demonstrates its ability to represent the temporal variability of the Denmark Strait overflow properties. Hypotheses are tested in Sects. 4, 5 and 6 and the results discussed, and a summary is given in Sect. 7.

\section{Salinity time series at the Angmagssalik moorings}

Since 1986 the Centre for Environment, Fisheries and Aquaculture Science (Cefas) in the UK, with colleagues in Germany (University of Hamburg) and Finland (Finnish Institute of Marine Research), have instrumented the core of the overflow plume $500 \mathrm{~km}$ south of Denmark Strait at Angmagssalik, as part of various EU-funded projects including Variability of Exchanges in the Northern Seas (VEINS), ArcticSubarctic Ocean Fluxes (ASOF) and Thermohaline Overturning - at Risk? (THOR) (Dickson and Brown, 1994; Dickson et al., 2008). Typically, a "picket fence" array of 7 or 8 current meter moorings is deployed annually, normal to the southeast Greenland Slope to intercept the descending overflow plume (Fig. 1, Section AB). Initially, only current velocity and temperature were monitored (Dickson and Brown, 1994), but from 1998 onwards, a variable number of SBE37 MicroCAT salinity sensors were also deployed across the array (Table 1).

For this investigation, salinity time series from four moorings F2, UK1, G1 and UK2 are analysed (Dickson et al., 2008). These instruments are located at depths of $1760 \mathrm{~m}$, $1970 \mathrm{~m}, 2180 \mathrm{~m}$ and $2350 \mathrm{~m}$ respectively (Table 1). Figure $2 \mathrm{a}$ shows a vertical section through the moorings, with $\sigma_{\theta}$ and salinity obtained from CTD casts during the June 2009 RV Maria S. Merian 12-1 cruise (Quadfasel, 2009). The salinity and density are typical for the overflow $500 \mathrm{~km}$ south of the sill (Dickson and Brown, 1994). The bottom water mass, forming the core of the overflow, is DSOW. Between a depth of about $1500 \mathrm{~m}$ and the 27.85 isopycnal lies Iceland Scotland Overflow Water (ISOW), which is the overflow water entering the North Atlantic through the Faroe Bank Channel. This circulates round the Reykjanes Ridge (Fig. 1) into the Irminger Basin, and usually has a $\sigma_{\theta}>27.8$ and salinity between 34.91 and 34.93 (Fogelqvist et al., 2003). The 27.8 isopycnal separates ISOW from the overlying Labrador Sea Water (LSW), formed by wintertime convection in the Labrador Sea (Yashayaev, 2007) and Irminger Sea (Pickart 
Table 1. Locations, depths and deployment dates of moorings in Fig. 2.

\begin{tabular}{|c|c|c|c|c|c|}
\hline Mooring & Location & $\begin{array}{l}\text { Instrument } \\
\text { depth }(\mathrm{m})\end{array}$ & $\begin{array}{l}\text { Height above } \\
\text { sea bed }(\mathrm{m})\end{array}$ & $\begin{array}{c}\text { Water } \\
\text { depth }(m)\end{array}$ & $\begin{array}{l}\text { Deployment } \\
\text { dates }\end{array}$ \\
\hline $\mathrm{F} 2$ & $\begin{array}{l}63.55^{\circ} \mathrm{N} \\
36.50^{\circ} \mathrm{W}\end{array}$ & 1760 & 20 & 1780 & $\begin{array}{l}15 \text { July } 2003 \text { to } \\
27 \text { July } 2005\end{array}$ \\
\hline UK1 & $\begin{array}{l}63.48^{\circ} \mathrm{N} \\
36.29^{\circ} \mathrm{W}\end{array}$ & 1970 & 20 & 1990 & $\begin{array}{l}24 \text { August } 1998 \text { to } 19 \text { August } 1999 \\
10 \text { August } 2000 \text { to } 01 \text { July } 2001\end{array}$ \\
\hline G1 & $\begin{array}{l}63.37^{\circ} \mathrm{N} \\
36.07^{\circ} \mathrm{W}\end{array}$ & 2180 & 20 & 2200 & $\begin{array}{l}10 \text { August } 2000 \text { to } \\
13 \text { June } 2002\end{array}$ \\
\hline UK2 & $\begin{array}{l}63.27^{\circ} \mathrm{N} \\
35.87^{\circ} \mathrm{W}\end{array}$ & 2350 & 18 & 2368 & $\begin{array}{l}15 \text { July } 2003 \text { to } \\
27 \text { July } 2005\end{array}$ \\
\hline
\end{tabular}

et al., 2003). The upper limit of LSW occurs at a depth of about $500 \mathrm{~m}$, where the 27.70 isopycnal separates the surface and deep water masses (Holliday et al., 2007). The moorings are positioned directly in the core of the dense overflow, ideal for monitoring the temporal variability of DSOW salinity (Fig. 2a). Salinity values have been calibrated against CTD data obtained at the start and end of each mooring deployment. No long-term drift was detected in any of the instruments. Data were binned into $1 \mathrm{~h}$ means from the original 10 min sampling rate, and tidal signals were removed using the T_TIDE MATLAB harmonic analysis toolbox (Pawlowicz et al., 2002) (Fig. 3).

Strong interannual and intra-annual variation is evident, with fresh anomalies in the overflow core in the early months of most years. Although the negative anomalies all appear in the first half of each year, they do not all occur during the same months and are of significantly varying amplitude. Fourier analysis shows the seasonal cycle to be negligible and therefore we have not removed a seasonal cycle from the salinity time series. There is a temporary reduction in salinity of around 0.04 between January 2004 and July 2004, peaking at 0.06 in May 2004. The May 2004 event represents a change of around 3 standard deviations of hourly values from the 1998 to 2005 mean of 34.87 . This event is identified with the same magnitude at three of the adjacent moorings spanning a distance of about $40 \mathrm{~km}$ (Fig. 3), so malfunction in a single instrument can be eliminated as a cause. This also suggests that the 2004 fresh anomaly is unlikely to have been caused by a lateral movement of the DSOW plume core across the continental slope, because each mooring would have measured a different value for salinity if the plume changed position and encompassed more or fewer of the moorings. In addition, there is no significant statistical relationship between salinity and velocity at UK1 (Fig. 4) (correlation coefficients $r=-0.11$ for zonal velocity and $r=-0.03$ for meridional velocity). This reinforces the evidence that the fresh anomaly was not caused by lateral movements in the DSOW core, or by a variation in the overall plume transport.

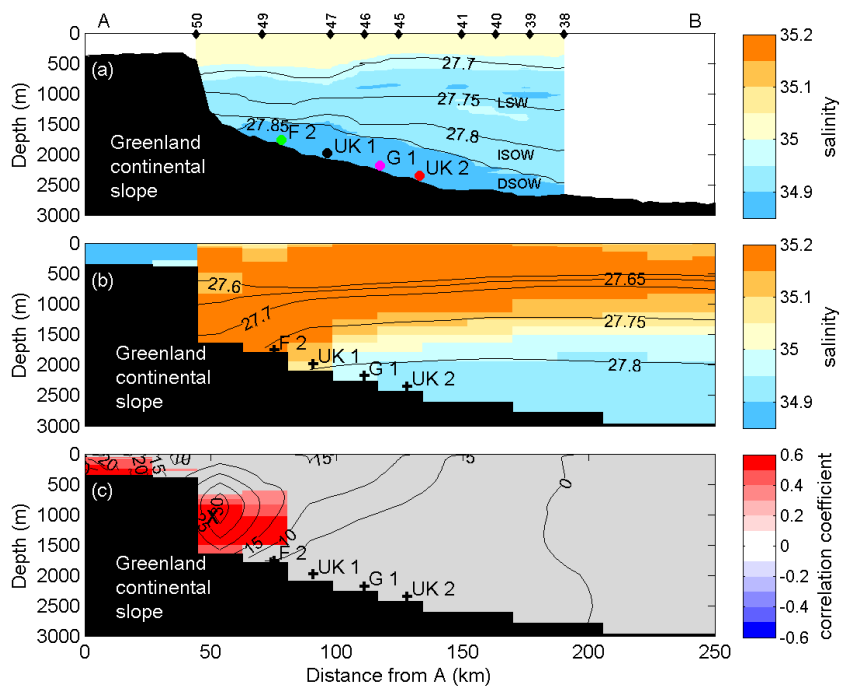

Fig. 2. (a) Cross-section AB (see Fig. 1 for location) showing locations of moorings F2, UK1, G1 and UK2, at the depths at which salinity measurements were obtained. Contours and shading represent $\sigma_{\theta}$ and salinity respectively, obtained from CTD casts during the June 2009 MSM 12-1 cruise. Numbers along top indicate CTD deployments. (b) Section through the Angmagssalik moorings in OCCAM, showing the mean June salinity between 1994 and 2004. Contours indicate the 11-year mean of OCCAM $\sigma_{\theta}$. (c) Section through the Angmagssalik moorings in OCCAM, showing the correlation coefficient between mooring UK1 salinity anomaly time series and the equivalent OCCAM salinity anomaly time series in each grid cell $(p<0.01)$. Contours indicate the 11 -year mean of OCCAM current velocity $\left(\mathrm{cm} \mathrm{s}^{-1}\right)$ normal to section $\mathrm{AB}$ (positive values indicate southwestward flow). Grey indicates no statistically significant correlation.

The salinity time series (Fig. 3) also displays high, but not dominant, variability over periods of 4 to 10 days. Dickson and Brown (1994) analysed current and temperature records at the Angmagssalik array, and found similar, though dominating, variability on timescales of 1 to 12 days. This is caused by mesoscale eddies passing through the moorings. 


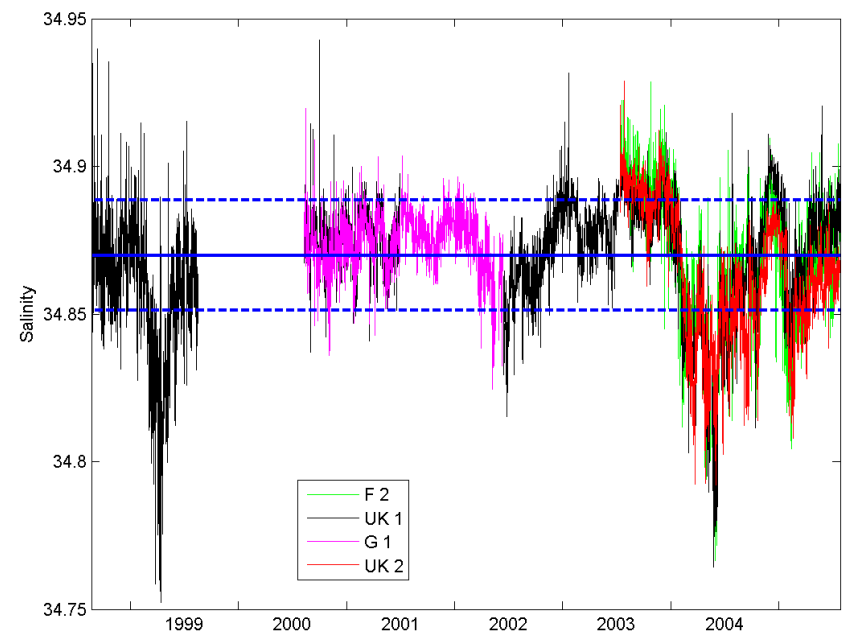

Fig. 3. Salinity time series from the Angmagssalik array Sea-Bird MicroCATs (Dickson et al., 2008). Data have been binned into $1 \mathrm{~h}$ means from the original $10 \mathrm{~min}$ sampling rate. Solid blue line represents the mean of the time series, and dotted blue lines represent plus and minus 1 standard deviation. Tidal signals have been removed.

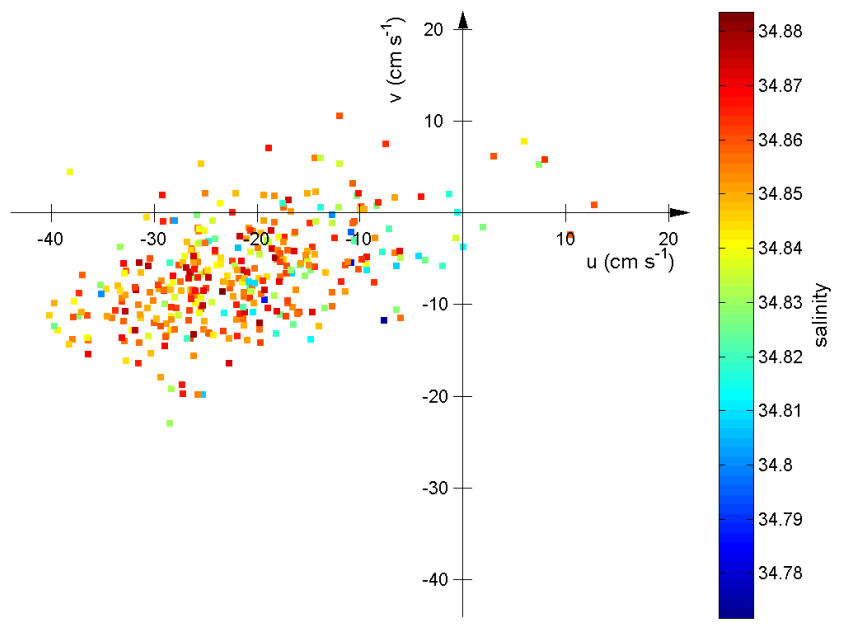

Fig. 4. Scatterplot of UK1 current meter velocity eastward (u) and northward (v) components coloured by UK1 salinity for the period August 1998 to December 2004. Data have been binned into 5-day means and tidal signals have been removed.

To remove these from the salinity time series, a first order low-pass Butterworth filter with a cut-off period of 30 days was applied. To produce a continuous salinity time series between August 2000 and July 2005, G1 salinity data were used to fill the gap in the UK1 time series between July 2001 and June 2002 (Fig. 3). UK1 and G1 are adjacent in the array, and display almost identical values of salinity (Fig. 3). The correlation coefficient between the two filtered time series for August 2000 to July 2001 is $0.91(p<0.01)$, so we can be confident that G1 and UK1 are monitoring the same flow.
Based on the current understanding of how the source of the overflow originates upstream of the sill, and the nature of its descent towards the North Atlantic (Dickson and Brown, 1994; Rudels et al., 2002), we formulate three hypotheses (H1, H2 and H3) to explain the cause of the 2004 negative salinity anomaly at Angmagssalik. $\mathrm{H} 2$ is broken down into five sub-hypotheses (H2a, H2b, H2c, H2d and H2e).

- H1 the 2004 anomaly resulted from processes occurring between the overflow sill and the moorings associated with anomalous mixing or water mass pathways.

- H2 the 2004 anomaly was caused by a change in salinity of the source waters feeding the overflow at the sill.

- H2a the 2004 anomaly originated from glacial ice melt anomalies upstream of the sill.

- H2b the 2004 anomaly originated from precipitation anomalies upstream of the sill.

- H2c the 2004 anomaly originated from sea-ice melt anomalies upstream of the sill.

- H2d the 2004 anomaly was caused by a change in the salinity of the source waters originating from the inflowing Atlantic Water (AW) to the Nordic Seas

- H2e the 2004 anomaly was caused by a change in the salinity of the source waters originating from water flowing southwards in the EGC from the Arctic

- H3 the 2004 anomaly was caused by changes in the proportion of different source waters feeding the overflow.

Hypotheses $\mathrm{H} 1$ and $\mathrm{H} 2$ will be tested using the output from an OGCM, and $\mathrm{H} 3$ using the reanalysis data that force the model as well as the model output.

\section{The Ocean Circulation and Climate Advanced Modelling (OCCAM) model}

The OGCM selected is the Ocean Circulation and Climate Advanced Modelling (OCCAM) project model. The OCCAM model (run by the National Oceanography Centre, Southampton) is a high resolution, primitive equation OGCM, covering a global domain from the Southern Ocean at $78.5^{\circ} \mathrm{S}$ to $90^{\circ} \mathrm{N}$. It has a $1 / 12^{\circ}$ horizontal resolution, and 66 vertical layers of progressively increasing thickness from $5 \mathrm{~m}$ near the surface to $200 \mathrm{~m}$ in the deep ocean (http://www.noc.soton.ac.uk/JRD/OCCAM; Coward and de Cuevas, 2005). The model has a rotated grid over the North Atlantic, and is forced with $6 \mathrm{~h}$ zonal and meridional $10 \mathrm{~m}$ wind stress from the National Centres for Environmental Prediction (NCEP) global reanalysis (Kalnay et al., 1996). It also incorporates a free surface, partial bottom cell scheme 
and sea-ice model. Its ability to represent boundary currents, frontal systems and eddy fields, combined with an accurate representation of small scale topographic features and sea-ice behaviour, makes it a suitable tool to examine the dynamical processes occurring upstream of Denmark Strait. Mixing in the model consists of (a) vertical diffusion, constant below the mixed layer $\left(10^{-5} \mathrm{~m}^{2} \mathrm{~s}^{-1}\right)$ and dependent on the available energy in the mixed layer, and (b) implicit horizontal mixing resulting from the advection scheme, that increases with horizontal velocity. There is no explicit mixing along isopycnals or horizontally. Hence the numerical mixing smoothes tracer structure at the grid scale, and the resolved eddies mix at larger length scales. There is also convection where the water column becomes statically unstable, completely mixing any unstable part of the water column. The layered depth structure can limit the ability of OCCAM to correctly reproduce vertical mixing, which may result in an unrealistic representation of the overflow plume as it descends from the sill to the moorings (Saunders et al., 2008). However, processes upstream of the sill that predominantly determine DSOW properties mainly occur in the highly resolved top $600 \mathrm{~m}$ of the water column, so this limitation of OCCAM should not significantly reduce its suitability for use in this study that focuses on processes upstream of Denmark Strait. Five-day means from OCCAM run 401 were obtained for the period January 1988 to December 2004. Some long-term drift is present in temperature and salinity during model spin-up between 1988 and 1993, but is negligible thereafter.

We are not expecting the model to represent accurately the details of the overflow downstream of the Denmark Strait sill, where large vertical gradients in tracer properties and velocity, combined with steep bathymetry, lead to strong localised mixing and entrainment, which the model cannot accurately reproduce. However the processes that occur in the ocean upstream of the sill should be represented reasonably by the model. Therefore we use OCCAM as a tool to examine the potential mechanisms originating upstream of the sill that may drive the variability of the observed salinity at Angmagssalik.

We now examine the structure of the overflow at the moorings in OCCAM. The mean June OCCAM salinity and density between 1994 and 2004 across a section equivalent to the location of the Angmagssalik array (Fig. 2b) show a broadly similar structure to the observations (Fig. 2a), but with significant differences related to the overflow plume. In the observations the freshest water is associated with the overflow plume in the region of the mooring array (Fig. 2a), whereas in OCCAM the core of the overflow plume is located closer to the continental shelf at a shallower depth, and has a weaker salinity minimum of $\sim 35.1$ (Fig. $2 b$ ). This confirms that the Denmark Strait overflow plume, as represented by the model, differs significantly from that observed. The model has a core of high velocity water originating from the Denmark Strait sill (Fig. 2c), but it is too buoyant due to excessive mixing and entrainment, and consequently is too high in the water column. This is due to the imperfect ability of the model to accurately represent vertical mixing processes, which occur as the plume makes its rapid descent from the sill. The model is unlikely to represent entrainment well, as vertical mixing is not stratification-dependent, and the vertical resolution is insufficient to resolve the overflow plume.

The mean OCCAM velocity perpendicular to the Angmagssalik section (Fig. 2c) clearly identifies the high velocity core of the overflow, with a maximum mean velocity of about $30 \mathrm{~cm} \mathrm{~s}^{-1}$ in the centre of the core, reducing to about $5 \mathrm{~cm} \mathrm{~s}^{-1}$ at the outer edge of the overflow. The overflow core extends from a depth of $500 \mathrm{~m}$ to $1500 \mathrm{~m}$, with a width of about $35 \mathrm{~km}$, tightly hugging the East Greenland continental slope. Its location is bounded by the 27.6 and 27.7 isopycnals (Fig. 2b). Passive tracer releases in OCCAM showed that this plume is fed from denser water than the fresh current on the shelf, separated from the EGC core in the region of the sill. With respect to velocity, the OCCAM overflow is in good agreement with data obtained from the Angmagssalik moorings, that range from around 20 to $40 \mathrm{~cm} \mathrm{~s}^{-1}$ (Dickson and Brown, 1994). The volume flux of the dense overflow in OCCAM from August 1998 to December 2004, calculated by integrating the net transport for $\sigma_{\theta}>27.6$ from the Greenland continental slope to $150 \mathrm{~km}$ from point A (Fig. 2), is greater than that observed at Angmagssalik for the core of the Denmark Strait overflow plume (Fig. 5c) but at the lower end of the range of previous estimates for the total transport of the overflow in the area (Dickson and Brown, 1994). The mean observed transport in the core of the overflow, calculated by integrating the fluxes measured by current meters $\mathrm{UK} 1$, UK2 and G1 for $\sigma_{\theta}>27.85$, was $2.2 \mathrm{~Sv}$ with a standard deviation of $0.3 \mathrm{~Sv}$ (Fig. 5c, see also Fig. 19.7 of Dickson et al., 2008). The transport calculated for the full mooring array of 6 current meters (F1, F2, UK1, UK2, G1, G2) for $\sigma_{\theta}>27.85$ yielded a mean flux of $4.0 \mathrm{~Sv}$ with a standard deviation of $0.36 \mathrm{~Sv}$ (Fig. 5c, see also Fig. 19.7 of Dickson et al., 2008). For OCCAM, the transport of water denser than 27.6 was $6.0 \mathrm{~Sv}$ with a standard deviation of $0.83 \mathrm{~Sv}$ (Fig. 5c). Dickson and Brown (1994) calculated a volume flux for $\sigma_{\theta}>27.8$ of $10.7 \mathrm{~Sv}$ at Angmagssalik and 5.2 Sv just $160 \mathrm{~km}$ closer to the sill, showing that volume fluxes are highly variable spatially. Direct comparisons between the observed and modelled volume transports are compromised by the undefined boundaries and differing structure of the plumes, but we conclude that, given the differing mixing and entrainment regime, OCCAM represents the transport of the overflow at Angmagssalik to a reasonable degree of accuracy both in terms of magnitude and variability.

We now show that despite the model's limitations in the spatial representation of the overflow plume's location, the observed salinity anomaly in 2004 also occurs in the OCCAM model. We first examine the temporal variability of the salinity in the overflow as represented in OCCAM. We conduct zero time-lagged regression analysis between 

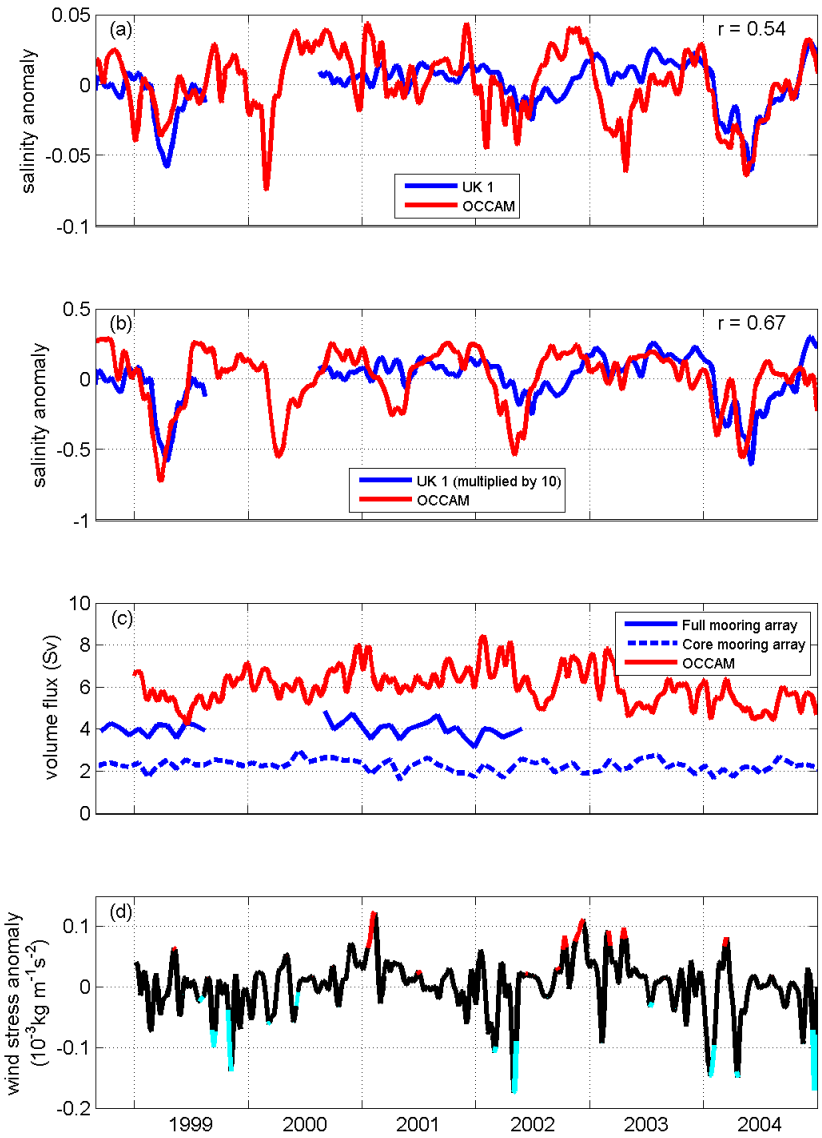

Fig. 5. (a) UK1 (blue) and OCCAM (red) salinity anomaly time series. OCCAM time series taken from location marked " $\mathrm{X}$ " in Fig. 2c. For the whole time series, the correlation coefficient $r=0.54$; for 2004 only, $r=0.96(p<0.01)$. (b) UK1 (blue) and OCCAM (red) salinity anomaly time series. OCCAM time series taken from location marked "+" in Fig. 6. The maximum value of $r=0.67(p<0.01)$ occurs for a time lag of 6 weeks. UK1 time series is multiplied by 10 to allow direct comparison of both time series. (c) Volume flux of the observed complete mooring array (F1, $\mathrm{F} 2$, UK1, UK2, G1, G2) and core mooring array (UK1, UK2, G1) for $\sigma_{\theta}>27.85$ (solid blue and dashed blue line respectively) (from Fig. 19.7 of Dickson et al., 2008). Red line represents OCCAM volume flux calculated by integrating net transport for $\sigma_{\theta}>27.6$ between the Greenland continental slope and $150 \mathrm{~km}$ from point A (Fig. 2b). (d) NCAR meridional wind stress anomaly at the grid cell of highest correlation $(r=0.53, p<0.01)$ at $75^{\circ} \mathrm{N} 20^{\circ} \mathrm{W}$ in Fig. 10a. A time lag of 4.5 months has been applied to the time series. Seasonal cycle has been removed. For each calendar month, the three maximum (red) and minimum (cyan) wind stress anomalies over the 6 year period are used to composite salinity, velocity and sea surface height.

UK1 salinity anomaly time series, and OCCAM salinity anomaly time series in each grid cell across the same section (Fig. 2c). To maintain consistency between both time series, the UK1 data were binned into 5-day means and the time series truncated to 31 December 2004, and a first order low-pass Butterworth filter with a cut-off period of 30 days was applied to the OCCAM data.

A region of coherent, high correlation exists between UK1 mooring salinity and OCCAM salinity, corresponding almost exactly with the region of highest velocity (Fig. 2c). At the position marked " $\mathrm{X}$ " on Fig. 2c, the correlation coefficient for the whole time series was $0.54(p<0.01)$, and increased to 0.96 ( $p<0.01$ ) for 2004 only (Fig. 5a), implying that this region in OCCAM is responding to the same dynamical process influencing the overflow salinity as the ocean. This makes it a suitable tool for investigating the underlying mechanisms responsible for salinity variability at Angmagssalik. We note that the time series are also highly correlated when 2004 is excluded, so these mechanisms should be applicable generally. Nonetheless we shall focus primarily here on possible mechanisms causing the 2004 anomaly.

\section{Testing of hypothesis $\mathrm{H1}$ - the 2004 anomaly resulted from processes occurring between the overflow sill and the moorings associated with anomalous mixing or water mass pathways}

If it can be demonstrated that OCCAM identifies the anomaly at the overflow sill, on the correct density layer, and with a time-lag equivalent to the transit time for this water to travel between the sill and the moorings, this would strongly suggest that processes upstream of the sill are responsible for causing the anomaly at the moorings. It would also signify that it is unlikely to be mechanisms occurring between the sill and the moorings, such as entrainment and mixing with ISOW and LSW that are producing the anomaly. Hence in that case the anomaly must form upstream of the sill, and advect from the sill to the moorings in the dense overflow, meaning that hypothesis $\mathrm{H} 1$ can be rejected.

A time-lagged regression analysis was performed between the UK1 salinity anomaly time series and OCCAM salinity anomaly time series in each grid cell across a section through the sill. Figure 6 clearly shows a region of coherent, high correlation between time series of UK1 mooring salinity anomaly and OCCAM salinity anomaly, between depths of about $150 \mathrm{~m}$ to $350 \mathrm{~m}$, and $60 \mathrm{~km}$ to $180 \mathrm{~km}$ from the Greenland coast. The highest correlation coefficient was 0.67 $(p<0.01)$ (marked "+" on Fig. 6), and occurred at a time lag of 6 weeks (Fig. 5b). Its location just beneath the 27.6 isopycnal corresponds closely with the value of 27.65 obtained for the density of the core of the overflow in OCCAM (Fig. 2b). This implies that water at the sill, at the location marked "+" on Fig. 6, is probably the same water causing the anomaly at the moorings.

In addition to 2004, Fig. 5a and b show that strong negative anomalies are measured by UK1 during 1999 and 2002. The 1999 event is similar in magnitude to the 2004 anomaly, but shorter in duration, extending between March and June. The negative anomalies in 1999 and 2002 are also present in 


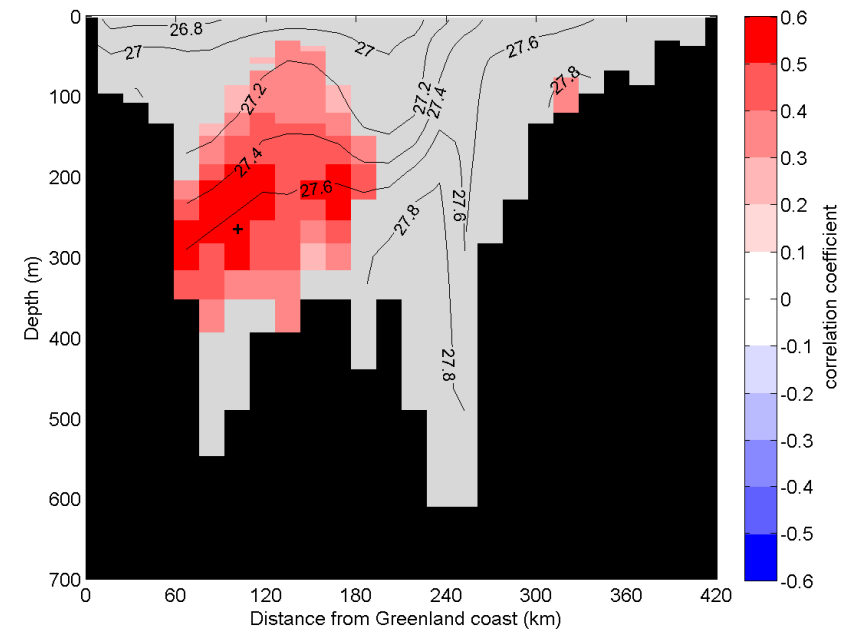

Fig. 6. Section through the overflow sill in OCCAM, showing the correlation coefficient between mooring UK1 salinity anomaly time series and the equivalent OCCAM salinity anomaly time series in each grid cell $(p<0.01)$. Contours indicate the 11-year mean of OCCAM potential density. Grey indicates no statistically significant correlation.

OCCAM at the sill and, less convincingly, in OCCAM at the moorings. In 2001 and 2003 only very weak negative anomalies are present at UK1. Weak anomalies are present in OCCAM at the sill for both 2001 and 2003, and in OCCAM at the moorings for 2001. This suggests that the mechanism responsible for the 2004 negative salinity anomaly is probably always occurring throughout the time series, but other processes may dominate in different years. The UK1 time series correlates most highly with the OCCAM time series during 2004 both at the sill $(r=0.90, p<0.01, \mathrm{lag}=6$ weeks $)$ and the moorings ( $r=0.96, p<0.01$, lag $=0$ weeks), and one could argue that this may skew the correlation coefficients of 0.67 and 0.54 obtained for the whole time series (Fig. 5a and b). This may indicate that any proposed mechanism for causing salinity anomalies at the moorings only pertains to 2004 . However, regression analysis between UK1 salinity anomaly time series and OCCAM salinity anomaly time series at the sill and the moorings for 1999 to 2003 produced correlation coefficients of $0.65(p<0.01)$ and $0.26(p<0.01)$ respectively. This suggests that OCCAM is realistically representing the processes driving salinity anomalies upstream of the sill in all years, but that imperfect representation of mixing downstream of the sill in OCCAM results in the anomalies at the moorings in OCCAM being less clear for years other than 2004.
Although both time series in Fig. 5b display similar temporal variability, the amplitude of the anomalies at the sill in OCCAM is around 10 times that of mooring UK1. This could indicate that mixing and entrainment with surrounding water masses, that occur as the overflow plume descends the slope, dilute the anomaly to one tenth of its amplitude at the sill by the time it reaches the moorings. To test this, a passive tracer experiment was performed "off-line" using the OCCAM velocity and density fields to force the advection and diffusion equations for the tracer. The tracer was initialised at the sill in OCCAM, at grid cells within the density range $27.6<\sigma_{\theta}<27.8$, to correspond with the density of the water at location "+" in Fig. 6. A continuous release was used to permit the concentration of tracer downstream of the sill to stabilise over time, rather than be quickly flushed out of the system. The tracer was released continuously from 12 December 2003, to allow enough time for the concentration of tracer at the moorings to stabilise before the arrival of the anomaly in May 2004.

Figure 7 shows a time series of tracer concentration taken from the grid cell representing the core of the overflow in OCCAM at the moorings (marked " $X$ " in Fig. 2c). The tracer arrives at the moorings around 6 weeks after its release at the sill, signifying that the transit time from the sill to the moorings is the same as the time-lag obtained for the correlation analysis. Following its arrival at the moorings, the tracer concentration is around 10-15\% (Fig. 7). Thus water originating from the 27.6 to 27.8 density range at the sill comprises $10 \%$ to $15 \%$ of the water at the moorings. The 0.6 negative salinity anomaly present in this water at the sill in April 2004 (Fig. 5b) has most likely been diluted down to 0.06 at the moorings (Fig. 5a), by mixing with ambient downstream water masses of a higher salinity, in an approximate 9:1 ratio. In the real ocean, this ratio is likely to be lower $(\sim 6: 1)$ based on the higher volume flux found at the moorings in OCCAM than observed (Fig. 5c). Based on the presence of the negative salinity anomaly in OCCAM at the sill, and the results of this passive tracer experiment, we argue that hypothesis $\mathrm{H} 1$ can be rejected.

\section{Testing of hypothesis $\mathrm{H2}$ - the 2004 anomaly was caused by a change in salinity of the source waters feeding the overflow at the sill}

The 2004 negative salinity anomaly is present in OCCAM at the sill, and in the OCCAM plume at the latitude of the moorings. The temporal variability of glacial ice-melt is not present in OCCAM, therefore an increase in glacial ice-melt cannot cause the 2004 anomaly. Furthermore, records of observed rates of Greenland ice melt do not show any anomalies that could explain the 2004 event (Van den Broeke et al., 2009; Velicogna, 2009). Therefore hypothesis H2a can be rejected. 


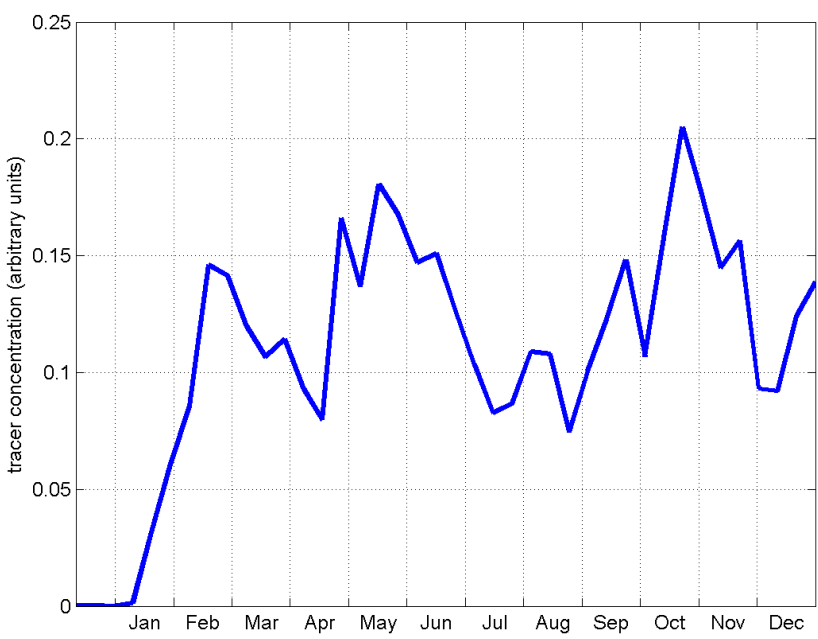

Fig. 7. Time series of passive tracer concentration at the OCCAM location of the overflow at the moorings, taken from grid cell at location marked " $X$ " in Fig. 2c. Passive tracer was initialised at the sill on grid cells with $27.6<\sigma_{\theta}<27.8$, on 12 December 2003, and continuously released until 31 December 2004. This water mass constitutes around $10-15 \%$ of the water present at location "X".

If precipitation or sea-ice melt anomalies were responsible for causing the 2004 negative salinity anomaly at the moorings, a time-lagged negative correlation would be expected between the OCCAM salinity anomaly time series at the sill, and time series of precipitation, or sea-ice melt anomalies upstream of the sill. An increased surface freshwater flux could reduce the salinity of the surface mixed layer, and these surface salinity anomalies could then propagate into the intermediate waters $(150 \mathrm{~m}$ to $600 \mathrm{~m})$ of the source regions, through wind-driven vertical turbulent diffusion at the base of the mixed layer, or deep winter convection. These anomalies might then be advected to the sill in the EGC, or the current originating in the Iceland Sea. So, a high upstream surface freshwater flux could result in a low salinity at the sill sometime later, indicated by a time-lagged negative correlation.

The only region of significant negative correlation between precipitation and OCCAM salinity is at Fram Strait (Fig. 8), with a time lag of 7 years. This suggests that negative salinity anomalies at the sill could be caused by increased precipitation in Fram Strait. However, passive tracer initialised at the surface in Fram Strait takes only about 2 1/2 years to mix with the intermediate layers of the EGC, and travel to the moorings (Fig. 9). Hence, the 7-year time lag is too long for this mechanism to be responsible for causing the 2004 anomaly, indicating that the negative correlation is probably due to chance. Rejection of hypothesis $\mathrm{H} 2 \mathrm{~b}$ is unsurprising, when one considers the freshwater flux required to cause the 2004 negative salinity anomaly at the moorings. Freshwater fluxes in the Arctic and Nordic Seas can be calculated according to a reference salinity of 35.2, which represents the salinity of inflowing AW to the Arctic Mediterranean (Dickson et al., 2007). Freshwater flux can then be calculated from the following equation:

$F_{\mathrm{w}}=V \times\left(1-\frac{S}{S_{\text {ref }}}\right)$

Assuming the volume flux of the dense overflow to be $3 \mathrm{~Sv}$ (Dickson and Brown, 1994), and given that the UK1 salinity time series shows an average reduction in salinity from a long term mean of 34.87 to 34.84 between January 2004 and July 2004 (Fig. 3), then an increased freshwater flux at the moorings of around $3 \mathrm{mSv}$ for this 6 month period would be needed to cause the anomaly. The net precipitation minus evaporation (P-E) over the whole of the Nordic Seas is only around $25 \mathrm{mSv}$ (Aagaard and Carmack, 1989), and the region of strong negative correlation in Fig. 8 occupies only around $2 \%$ of the surface area of the Nordic Seas. Therefore, only about $0.5 \mathrm{mSv}$ enters this region as a result of $\mathrm{P}-\mathrm{E}$, and this would have to increase by a factor of 6 , for 6 months, to provide enough freshwater to cause the anomaly. Moreover, the duration of the peak in tracer concentration at the moorings is around 1.5 years (Fig. 9), whereas the duration of the observed 2004 negative salinity anomaly is only about 6 months. This means that even in the unlikely event of an extremely high P-E input occurring capable of causing the anomaly at the moorings, the duration of its passage through the array would be too long to cause the anomaly shown in Fig. 3. Therefore hypothesis $\mathrm{H} 2 \mathrm{~b}$ is rejected on this ground as well as the unrealistic time lag, and unfeasibly high P-E requirement.

The correlation analysis between the OCCAM salinity anomaly time series at the sill and OCCAM sea-ice melt anomaly time series produced no regions of statistically significant correlation at any time lag, indicating that increased sea-ice melt is probably not responsible for causing the 2004 anomaly. Around $80 \mathrm{mSv}$ of sea-ice enters the Nordic Seas from the Arctic through Fram Strait (Dickson et al., 2007), and about $80 \%$ of this melts during transit in the EGC to Denmark Strait (Aagaard and Carmack, 1989), giving a liquid freshwater input of around $64 \mathrm{mSv}$. Therefore, only a $5 \%$ increase in sea-ice melt for a 6 month period would, in principle, provide enough freshwater to form the 2004 anomaly. So does our negative result eliminate this as a possibility, considering the relatively modest requirement of a $5 \%$ increase? During the time preceding the 2004 anomaly, no outstanding increase in OCCAM sea-ice melt occurred over a time period of one to several months. Even if a sufficient increase in seaice melt had occurred to cause the anomaly at the moorings, this freshwater would have probably remained at the surface, because of its low density, and flowed out through Denmark Strait in the surface waters of the EGC. So, this negative result can likely be accepted with a reasonable degree of confidence and consequently hypothesis $\mathrm{H} 2 \mathrm{c}$ is rejected.

To test hypotheses H2d and H2e, 11 year (1994 to 2004) time series of areally-weighted salinity of inflowing AW to 


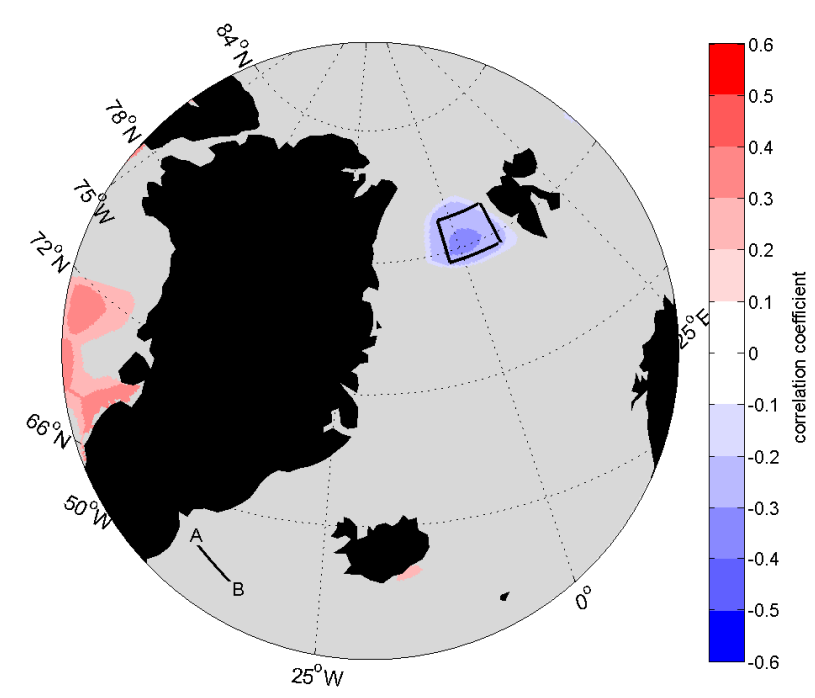

Fig. 8. Map of the time-lagged correlation coefficient between an 11 year time series (1994 to 2004) of the OCCAM sill salinity anomaly time series shown in Fig. 5b, and a 1994 to 2004 time series of CMAP 5 day mean precipitation (extracted from OCCAM) $(p<$ $0.01)$. Time lag is 7 years. Grey indicates no statistically significant correlation. Boxed area indicates region of passive tracer release.

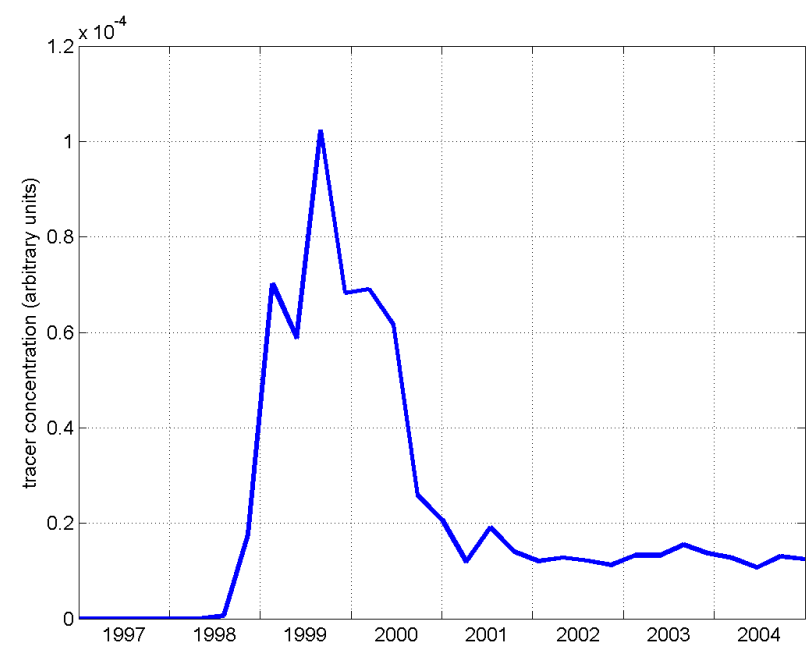

Fig. 9. Time series of passive tracer concentration at the OCCAM location of the overflow at the moorings, taken from the grid cell at location marked " $X$ " in Fig. 2c. Passive tracer was initialised at the surface in January 1997, and instantaneously released across the boxed region in Fig. 8.

the Nordic Seas across the Greenland-Scotland Ridge and of southward flowing EGC water through Fram Strait were extracted from OCCAM. AW was specified as northward flowing water with a potential temperature greater that $5^{\circ} \mathrm{C}$. EGC water was defined as southward flowing water with $\sigma_{\theta}>27.6$ situated between the surface and the depth of the Denmark Strait sill. This density range represents the EGC component of DSOW at the sill. No negative salinity anomalies large enough to have caused the 2004 anomaly were present at any time in either time series. Therefore, we argue that hypotheses $\mathrm{H} 2 \mathrm{~d}$ and $\mathrm{H} 2 \mathrm{e}$ can both be rejected.

\section{Testing of hypothesis $\mathrm{H3}$ - the 2004 anomaly was caused by changes in the proportion of different source waters feeding the overflow}

Given that changes in the proportion of different source waters feeding the overflow have previously been attributed to wind forcing variability (Holfort and Albrecht, 2007; Rudels et al., 2002, 2003), we now see whether a statistical relationship exists between mooring UK1 salinity data and the regional wind stress fields. A time-lagged regression analysis was performed between the UK1 salinity anomaly and NCAR 5 day mean meridional and zonal wind stress. Strong positive correlations were found between the meridional wind stress and UK1 salinity adjacent to the East Greenland coast between $72^{\circ} \mathrm{N}$ and $78^{\circ} \mathrm{N}$ (Fig. 10a). This region displayed a positive correlation for time lags ranging from 3 months to 6 months, with peak values of correlation coefficient at a lag of $4 \frac{1}{2} 2$ months $(r=0.53, p<0.01)$. Correlations between zonal wind stress and UK1 salinity showed weaker positive correlations peaking at the same time lag, further south across a smaller region between $70^{\circ} \mathrm{N}$ and $73^{\circ} \mathrm{N}$ (Fig. 10b). The correlation map shows that following a high southward wind stress off the east Greenland coast between about $70^{\circ} \mathrm{N}$ and $80^{\circ} \mathrm{N}$, a reduction in salinity at the moorings occurs around $41 / 2$ months later. This result is independent of the OCCAM model and suggests that hypothesis H3 may be true.

We assess the meteorological and oceanographic conditions that lead to the correlation of wind stress with the moored salinity by compositing the periods of positive (northward) and negative (southward) wind stress anomaly at section CD (marked on Fig. 10b), the location displaying the highest correlation coefficient with UK1 salinity (Fig. 5d). To minimise any potential bias from seasonal cycles in either the atmospheric or ocean data, two composite fields were compiled, one composite of the three most positive wind stress anomalies for each calendar month (marked red in Fig. 5d) and one composite of the three most negative wind stress anomalies for each calendar month (marked cyan in Fig. 5d). This process results in composites of fields from 36 positive (i.e. three Januaries with high wind stress, three Februaries, etc.) and 36 negative wind stress events, evenly distributed through the year. Figure 11 illustrates the composite atmospheric pressure anomalies and meridional wind stress anomalies. During the negative wind stress anomalies at section CD (Fig. 11a), the composite reveals a stronger than normal southward wind, associated with low atmospheric pressure in the middle of the Greenland Sea. During 

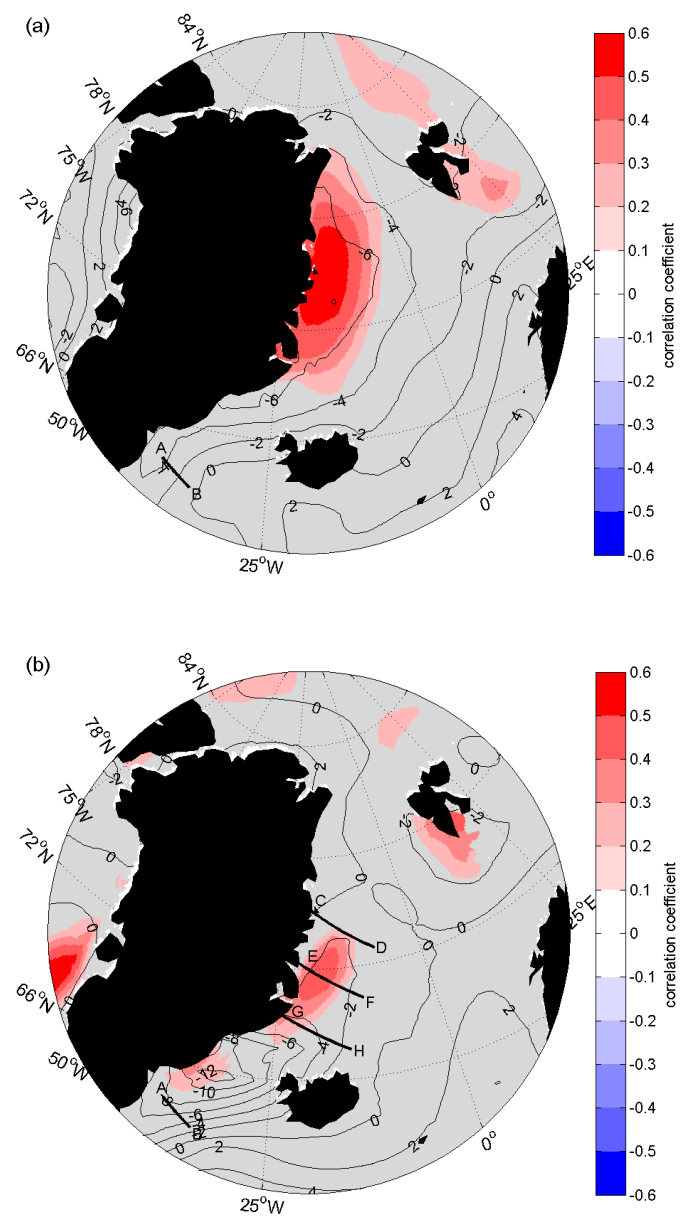

Fig. 10. Maps of the time-lagged correlation coefficient $(p<$ 0.01 ) between mooring UK1 salinity anomaly time series shown in Fig. 5a, and NCAR 5 day mean meridional wind stress (a) and zonal wind stress (b). Time lag is $4 \frac{1}{2} 2$ months. Contours indicate the 11-year mean of NCAR meridional and zonal wind stress $\left(10^{-3} \mathrm{~kg} \mathrm{~m}^{-1} \mathrm{~s}^{-2}\right)$. Grey indicates no statistically significant correlation. $\mathrm{CD}, \mathrm{EF}$ and $\mathrm{GH}$ are sections used to calculate the volume and freshwater flux of the EGC.

the positive wind stress anomalies (Fig. 11b), the composite reveals a weaker than normal southward wind, associated with high atmospheric pressure anomaly in the eastern Greenland Sea.

It is possible that an increase in the frequency of Greenland barrier wind events (Moore and Renfrew, 2005) may be responsible for the general driving of fresh anomalies occurring at Angmagssalik. Barrier wind events occur mainly in winter, and are strong southward winds blowing along the east coast of Greenland associated with the passage of individual low pressure systems (Moore and Renfrew, 2005). North of the sill in Denmark Strait at $67.7^{\circ} \mathrm{N} 25.3^{\circ} \mathrm{W}$ these events occur approximately once a week with a duration of several hours (Harden et al., 2011). However, a study into the frequency of barrier wind events in Denmark Strait between
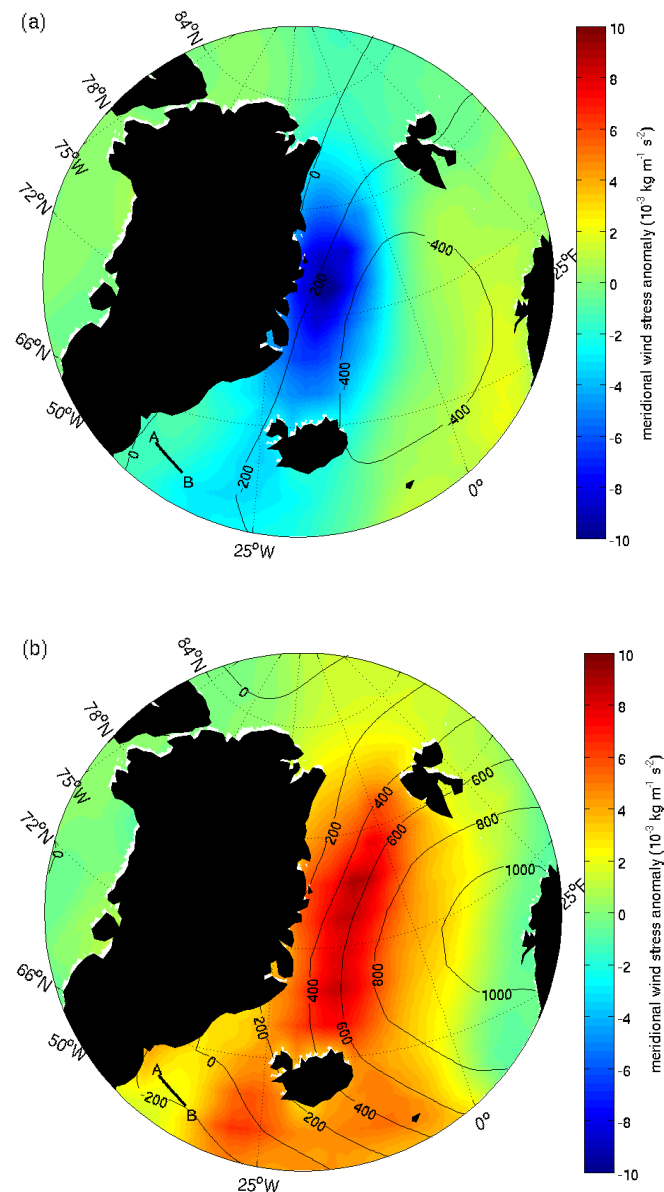

Fig. 11. Composite atmospheric sea level pressure anomalies (contours, in $\mathrm{Pa}$ ) and meridional wind stress anomalies (coloured shading) for negative $\mathbf{a}$ and positive $\mathbf{b}$ wind stress anomalies at section CD (see Fig. 10 for location). A negative anomaly denotes a stronger southward wind and a positive anomaly denotes a weaker southward wind.

1989 and 2009 (Harden et al., 2011) showed that 2004 was an unremarkable year with respect to the number of observed barrier wind events. Moreover, barrier wind events are not resolved in OCCAM, and Fig. 11 shows only a weak tendency for the winds to blow along the coast south of Denmark Strait. So the fact that the 2004 salinity anomaly appears in OCCAM both at the sill and the moorings suggests that an increase in the frequency of barrier wind events is not the cause of the anomaly.

A wind-induced reduction in the salinity of the intermediate EGC waters ( $150 \mathrm{~m}$ to $600 \mathrm{~m}$ depth) feeding the overflow could be caused by stronger mixing between these water masses and the fresh overlying Polar Surface Water. An elevated input of kinetic energy to the ocean surface from a high wind stress intensifies mixing at the surface and increases the depth of the mixed layer. Wind-driven vertical turbulent diffusion at the base of the mixed layer could then cause the 


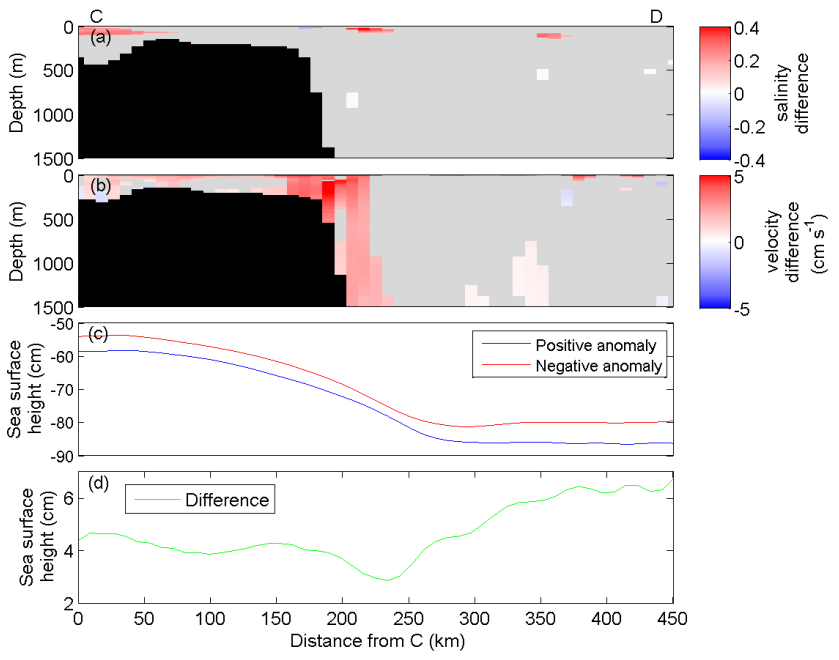

Fig. 12. Difference in salinity (a), and velocity (b) across section $\mathrm{CD}$, between times of strong positive and strong negative wind stress anomalies. Grey indicates no statistically significant difference $(p<0.01)$. (c) Sea-surface height across section CD during times of strong positive, and strong negative wind stress anomalies. Their difference is plotted in (d). The offset is due to the reduced atmospheric pressure during times of strong negative wind stress anomalies. The difference is statistically significant $(p<0.01)$. In all panels seasonal effects have been removed, by compositing the data on the 3 strongest positive and 3 strongest negative wind stress anomalies in each calendar month for 1999 to 2004 (full description in text).

transfer of surface mixed layer fresh anomalies into the underlying halocline. These anomalies could then be advected by the EGC from the region of formation to the moorings. To further test H3 using OCCAM as a tool, salinity, current velocity and sea surface height during times of positive and negative wind stress anomalies were composited as described above (Fig. 12). There is no statistically significant difference in the vertical salinity section at $75^{\circ} \mathrm{N}$ between times of strong southward and strong northward wind stress (Fig. 12a). This suggests that a wind-induced change in the salinity of the EGC is probably not responsible for freshening the overflow.

Alternatively, a stronger southward wind stress could cause a variation in the proportion of EGC water contributing to the overflow, by influencing the volume of EGC water transported to the sill. The velocity composite (Fig. 12b) shows a statistically significant $(p<0.01)$ increase in the southward velocity of the EGC of about $3 \mathrm{~cm} \mathrm{~s}^{-1}$, during times of strong southward wind stress, compared with times of weak southward wind stress. A stronger southward wind stress increases Ekman transport towards the west, causing water to pile up against the east Greenland coast. The steeper sea surface slope (Fig. 12c and d) creates a stronger seaward pressure gradient force (balanced by the Coriolis force), causing an increase in the southward EGC geostrophic velocity. The velocity increase is roughly uniform to a depth of about $600 \mathrm{~m}$ (Fig. 12b).

Can the results of the compositing exercise then explain the occurrence of the 2004 negative salinity anomaly at the moorings? Clearly, a water mass fresh enough and of the correct density to feed the overflow would need to be present in the EGC at $75^{\circ} \mathrm{N}$, and remain relatively conserved en-route to the sill. Arctic Atlantic Water (AAW), derived from the modification of Atlantic Water inflow to the Arctic, where it becomes colder and fresher, joins the EGC through Fram Strait and has the appropriate characteristics $\left(27.70<\sigma_{\theta}<\right.$ 27.95, and salinity between 34.45 and 34.9) (Rudels et al., 2002). One would expect a similar water mass to be present in OCCAM. So to further test $\mathrm{H} 3$ using the model, we extract salinity on surfaces of constant density from OCCAM 41/2 months before the appearance of the anomaly at the moorings. Figure 13 shows the mean January 200427.7 isopycnal in the Nordic Seas coloured by its salinity. This clearly shows water of the correct density and salinity to cause the 2004 anomaly, present in the EGC along the entire east Greenland coast $41 / 2$ months before the anomaly occurs at the moorings. It has been suggested that AAW is transported by a strongly barotropic EGC, steered by topography, as a distinct outflow from the Arctic through Fram Strait, flowing directly to Denmark Strait (Mauritzen, 1996; Woodgate et al., 1999). Mauritzen (1996) noted that negligible mixing occurs between the AAW, and the adjacent RAW to the east, as the two water masses flow southward from Fram Strait, forming the western limb of the wind-driven Greenland Sea Gyre. Therefore, with a suitable water mass and pathway identified, a feasible mechanism could be that a stronger southward wind stress at $75^{\circ} \mathrm{N}$ increases the southward velocity of the EGC, increasing the volume flux of relatively fresh AAW flowing directly to the sill. This water then mixes with the other source waters immediately upstream of the sill, to form the negative anomaly that is subsequently observed at the moorings. A passive tracer experiment was performed to determine whether the timescale of water masses in the EGC to travel from location CD to the moorings is consistent with the time lag of $41 / 2$ months between wind and salinity anomalies suggested by Fig. 10. Tracer was released instantaneously at section $\mathrm{CD}$ on grid cells with $\sigma_{\theta}>27.6$, representing the density of water forming the anomaly at the sill. The release was on 20 December 2003, approximately $4 \frac{1}{2} 2$ months before the appearance of the May 2004 anomaly at the moorings. Figure 14 shows that by 14 March 2004 the majority of the tracer is advected southward in the EGC, and by 22 June 2004 it has been transported further south to around $69^{\circ} \mathrm{N}$. Here, a split occurs in the tracer pathway, with some tracer advected southwestward into Denmark Strait in the EGC, and some advected southeastward towards the Faroe Bank Channel in the East Icelandic Current. By 9 November, the tracer has reached the moorings at section $\mathrm{AB}$, making the total transit time from $75^{\circ} \mathrm{N}$ to the moorings approximately 10 months. 


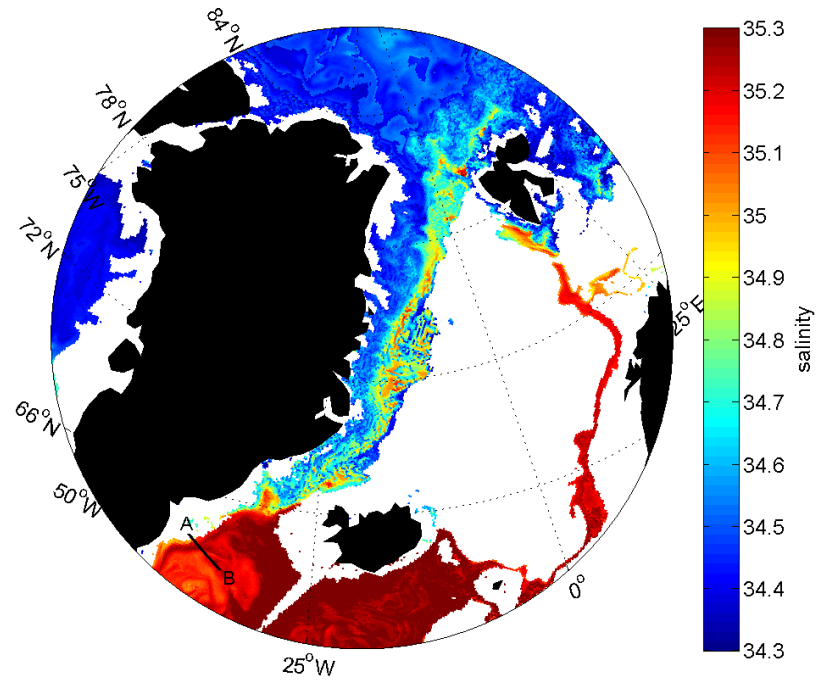

Fig. 13. The mean OCCAM January 200427.7 isopycnal coloured by salinity, showing water displaying the same salinity properties as Arctic Atlantic Water (34.45-34.9; Rudels et al., 2002) present along the east coast of Greenland.

So, to complete the story, an explanation is required for the 10 months taken for tracer released at $75^{\circ} \mathrm{N}$ to reach the moorings, compared with the $41 / 2$ month lag between wind and salinity anomalies suggested by Fig. 10. Using OCCAM to analyse the volume and freshwater fluxes in the EGC at $75^{\circ} \mathrm{N}$ (Fig. 10b, section CD), and further south at $72^{\circ} \mathrm{N}$ (Fig. 10b, section EF) and $69^{\circ} \mathrm{N}$ (Fig. 10b, section $\mathrm{GH})$, provides an answer for this. Figure $15 \mathrm{a}$ and $\mathrm{b}$ show that the temporal variability of the vertically integrated freshwater and volume fluxes, between depths of $150 \mathrm{~m}$ and $600 \mathrm{~m}$ in the EGC at sections CD, EF and GH, is in phase at all three locations. This means that the EGC is displaying the same response to the meridional wind stress throughout most of its pathway between Fram Strait and Denmark Strait. In addition, an increase in the volume and freshwater flux at all 3 sections occurs around $41 / 2$ months before the UK1 anomaly (Fig. 15c). So the time lag of $4 \frac{1}{2} 2$ months that produced the maximum correlation between the meridional wind stress and $\mathrm{UK} 1$ salinity at $75^{\circ} \mathrm{N}$ (Fig. 10a) actually represents a lag of $4 \frac{1}{2} 2$ months between a strengthening of the EGC and the appearance of the anomaly at the moorings. Consequently, for the results of the tracer experiment to support the proposed mechanism, there must be a transit time of $4 \frac{1}{2} 2$ months for tracer to travel to the moorings from the point where the EGC splits from the Greenland Sea Gyre. Figure 14 reveals that this is indeed the case, showing tracer separating from the gyre as a distinct southwestward flow at about $69^{\circ} \mathrm{N}$, on 22 June 2004, and arriving at the moorings on 9 November 2004, a time period of approximately $41 / 2$ months. Hence we argue that hypothesis $\mathrm{H} 3$ can be accepted.
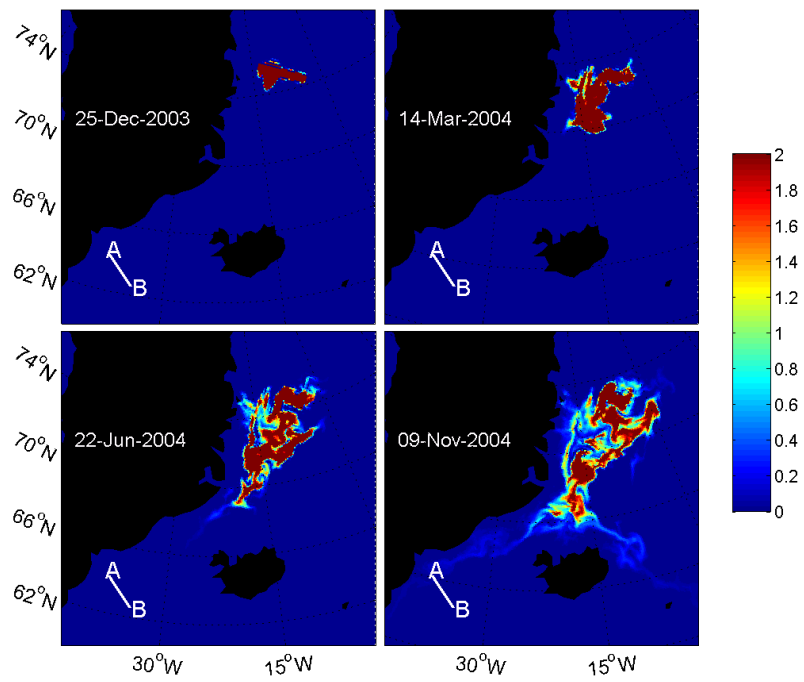

Fig. 14. Time-evolution of passive tracer, instantaneously released on 20 December 2003 across section CD. Tracer was initialised on grid cells with $\sigma_{\theta}>27.6$. Colour bar indicates vertically integrated tracer concentration in arbitrary units.

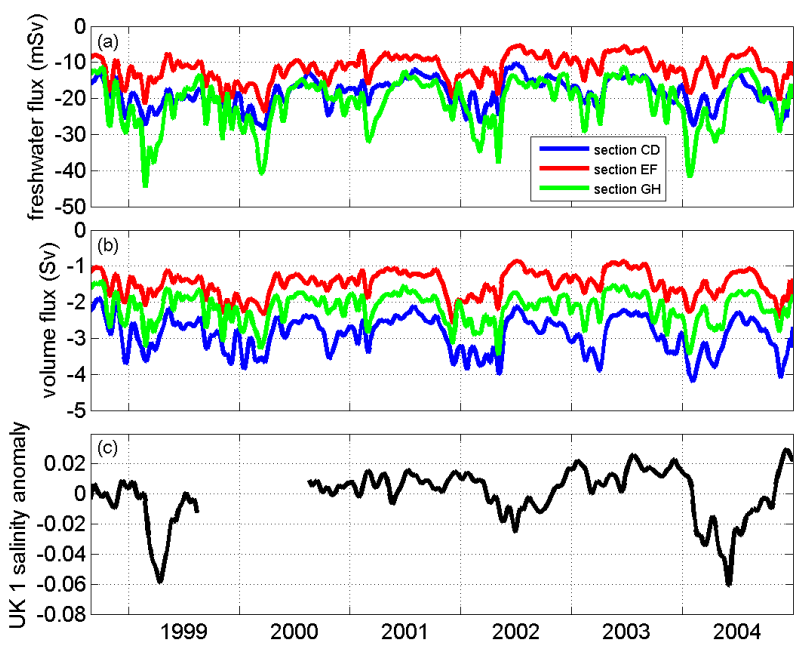

Fig. 15. Time series of freshwater flux (a) and volume flux (b), across sections CD, EF and GH shown in Fig. 10b. Freshwater flux has been calculated relative to a reference salinity of 35.2. Freshwater flux and volume flux have been integrated between depths of $150 \mathrm{~m}$ and $600 \mathrm{~m}$, to correspond with the depth of the Intermediate EGC water feeding the overflow. UK1 salinity anomaly time series is shown in (c).

\section{Summary}

Based on the results of Sect. 6, we propose a simple mechanism responsible for causing salinity anomalies in the Angmagssalik overflow plume (Fig. 16). An increased southward wind stress parallel to the east Greenland coast strengthens the whole EGC north of Denmark Strait. The 


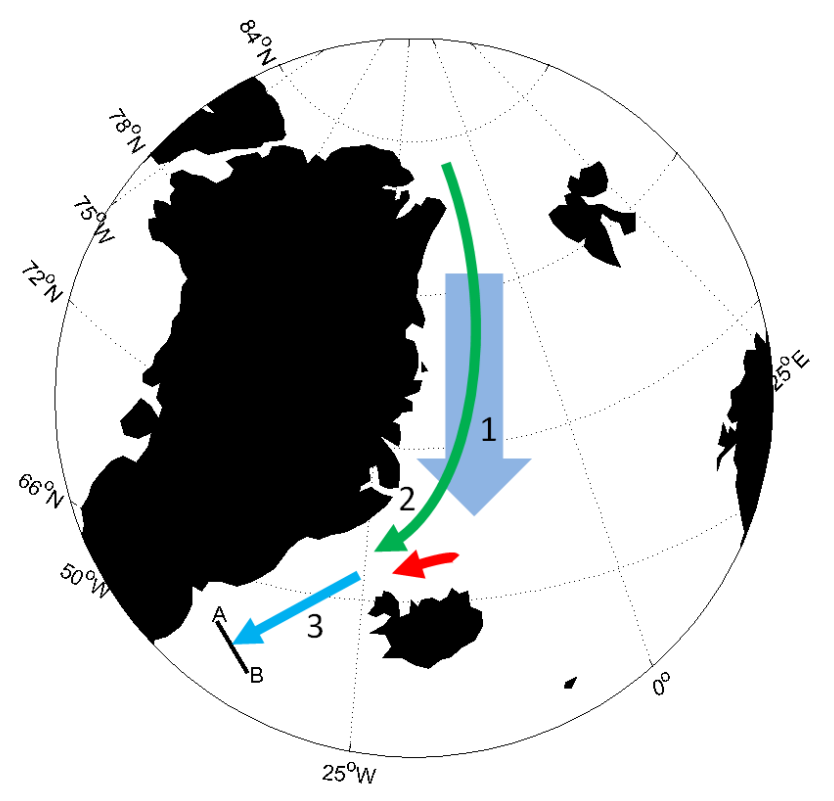

Fig. 16. The suggested mechanism controlling salinity anomalies at the Angmagssalik moorings (Section AB). 1. Southward wind stress increases. 2. Increase in volume flux of fresh intermediate EGC water arriving at the sill. 3. Freshening of Denmark Strait Overflow Water. Total time for whole process is $41 / 2$ months.

volume flux of fresh intermediate EGC water arriving at the sill is subsequently increased, resulting in a freshening of DSOW at the Angmagssalik moorings 41/2 months later.

Our results show that DSOW salinity anomalies are caused by changes in the proportions of source waters feeding the overflow, rather than changes in the salinity of the source waters. This is consistent with other research (Rudels et al., 2002, 2003; Holfort and Albrecht, 2007). However, in contrast to Rudels et al. (2003), we do not find evidence to support a complete switch between source regions (EGC or the Iceland Sea) causing changes in DSOW properties. While this suggests that the EGC is a permanent source for DSOW, the variability of which is crucial in modifying the properties of DSOW, we have no evidence to eliminate the Iceland Sea as another permanent source. Our study also supports the proposed mechanism by Holfort and Albrecht (2007), who argue that stronger southward winds result in more northern, low saline water flowing towards Denmark Strait. However we show that it is the action of the wind over a wide area of the Nordic Seas controlling the strength of the EGC, rather than the variability in the wind stress local to Denmark Strait, that modifies the salinity of the deep overflow. These results are significant because they highlight the importance of the EGC in modifying the salinity of DSOW. The freshening of DSOW and the associated reduction in density of NADW, could lead to a weakening of the meridional overturning circulation. It is therefore important that climate models used to predict the response of the global thermohaline circulation to anthropogenic climate forcing represent or parameterise the structure and variability of the EGC and the Denmark Strait overflow plume, and their response to regional atmospheric forcing. Poor representation of the EGC and the Denmark Strait overflow in climate models may result in the larger scale impact of salinity variability on the thermohaline circulation being incorrect, and future changes in climate may not be accurately predicted.

Acknowledgements. We thank Andrew Coward and the OCCAM team at the National Oceanography Centre, Southampton, for their help and providing the model results. The research presented in this paper was carried out on the High Performance Computing Cluster supported by the Research Computing Service at the University of East Anglia. The research leading to these results has received funding from the European Community's 7th framework programme (FP7/2007-2013) under grant No. GA212643 (THOR: "Thermohaline Overturning - at Risk", 2008-2012) and from Defra projects SD0440 \& ME5102. We thank the many chief scientists and crew completing the annual deployment of the Angmagssalik Array, which is a collaboration between the University of Hamburg, the Finnish Institute of Marine Research and Cefas. SH was funded by a NERC CASE award at the University of East Anglia supported by Cefas project DP239.

Edited by: M. Hecht

\section{References}

Aagaard, K. and Carmack, E.: The Role of Sea Ice and Other Fresh Water in Arctic Circulation, J. Geophys. Res., 94, 14485-14498, 1989.

Coward, A. and de Cuevas, B.: The OCCAM 66 Level Model: physics, initial conditions and external forcing, SOC Internal Report No. 99, National Oceanography Centre, Southampton, UK, 2005.

Curry, R., Dickson, B., and Yashayaev, I.: A change in the freshwater balance of the Atlantic Ocean over the past four decades, Nature, 426, 826-829, 2003.

Dickson, R. R. and Brown, J.: The production of North Atlantic Deep Water: Sources, rates and pathways, J. Geophys. Res., 99, 12319-12341, 1994.

Dickson R. R., Yashayaev, I., Meincke, J., Turrell, W. R., Dye, S. R., and Holfort, J.: Rapid Freshening of the Deep North Atlantic over the past Four Decades, Nature, 416, 832-837, 2002.

Dickson, R. R., Rudels, B., Dye, S., Karcher, M., Meincke, J., and Yashayaev, I.: Current estimates of freshwater flux through Arctic and subarctic seas, Prog. Oceanogr., 73, 210-230, 2007.

Dickson, R. R., Dye, S. R., Jónsson, S., Köhl, A., Macrander, A., Marnela, M., Meincke, J., Olsen, S., Rudels, B., Valdimarsson, H., and Voet, G.: The overflow flux west of Iceland: variability, origins and forcing, pages 443-474, in: Arctic Sub-Arctic Ocean fluxes: Defining the role of the Northern Seas in Climate, edited by: Dickson, R., Meincke, J., and Rhines, P., Springer, 734 pp., 443-474, doi:10.1007/978-1-4020-6774-7_20, 2008.

Fogelqvist, E., Blindheim, J., Tanhua, T., Østerhus, S., Buch, E., and Rey, F.: Greenland-Scotland overflow studied by hydro- 
chemical multivariate analysis, Deep-Sea Res. Pt. 1, 50, 73-102, 2003.

Hansen, B. and Østerhus, S.: North Atlantic - Nordic Seas exchanges, Prog. Oceanogr., 45, 109-208, 2000.

Harden, B., Renfrew, I., and Petersen, G.: A climatology of barrier winds off southeast Greenland, J. Clim., 24, 4701-4717, doi:10.1175/2011JCLI4113.1, 2011.

Holfort, J. and Albrecht, T.: Atmospheric forcing of DSOW salinity, Ocean Science, 3, 411-416, 2007.

Holliday, N., Meyer, A., Bacon, S., Alderson, G., and de Cuevas, B.: Retroflection of part of the East Greenland Current at Cape Farewell, Geophys. Res. Lett., 34, L07609, doi:10.1029/2006GL029085, 2007.

Jónsson, S. and Valdimarsson, H.: A new path for the Denmark Strait overflow water from the Iceland Sea to Denmark Strait, Geophys. Res. Lett., 31, L03305, doi:10.1029/2003GL019214, 2004.

Kalnay, E., Kanamitsu, M., Kistler, R., Collins, W., Deaven, D., Gandin, L., Iredell, M., Saha, S., White, G., Woollen, J., Zhu, Y., Chelliah, M., Ebisuzaki, W., Higgins, W., Janowiak, J., Mo, K., Ropelewskia, C., Leetmaa, A., Reynolds, R., and Jenne, R.: The NCEP/NCAR reanalysis project, Bull. Amer. Meteor. Soc., 77, 437-495, 1996.

Köhl, A.: Variable source regions of Denmark Strait and Faroe Bank Channel overflow waters, Tellus A, 62, 551-569, 2010.

Mauritzen, C.: Production of dense overflow waters feeding the North Atlantic across the Greenland-Scotland Ridge, Part 1, Evidence for a revised circulation scheme, Deep-Sea Res. Pt. I, 43, 769-806, 1996.

Moore, G. W. K. and Renfrew, I.: Tip jets and barrier winds: A QuikSCAT climatology of high wind speed events around Greenland, J. Clim., 18, 3713-3725, 2005.

Pawlowicz, R., Beardsley, B., and Lentz, S.: Classical tidal harmonic analysis including error estimates in MATLAB using T TIDE, Comput. Geosci., 28, 929-937, 2002.

Peterson, B., McClelland, J., Curry, R., Holmes, R., Walsh, J., and Aagaard, K.: Trajectory Shifts in the Arctic and Subarctic Freshwater Cycle, Science, 313, 1061-1066, 2006.
Pickart, R., Straneo, F., and Moore, G. W. K.: Is Labrador Sea water formed in the Irminger Basin?, Deep-Sea Res. Pt. I, 50, 23-52, 2003.

Pickart, R., Torres, D., and Fratantoni, P.: The East Greenland spill jet, J. Phys. Oceanogr., 35, 1037-1053, 2005.

Quadfasel, D.: Summary Cruise Report RV MARIA S. MERIAN Cruise MSM12-1, Institut für Meereskunde, KlimaCampus, Universität Hamburg, Bundesstr. 53, D-20146 Hamburg, 2009.

Rudels, B., Fahrbach, E., Meincke, J., Budeus, G., and Eriksson, P.: The East Greenland Current and its contribution to the Denmark Strait overflow, J. Mar. Sci., 59, 1133-1154, 2002.

Rudels, B., Eriksson, P., Buch E., Budéus, G., Fahrbach, E., Malmberg, S-A., Meincke, J., and Mälkki, P.: Temporal switching between sources of the Denmark Strait overflow water, ICES Mar. Sci. Symp., 219, 319-325, 2003.

Saunders, P. M., Cunningham, S., de Cuevas, B., and Coward, A.: Comments on "Decadal Changes in the North Atlantic and Pacific Meridional Overturning Circulation and Heat Flux", J. Phys. Oceanogr., 38, 2104-2107, 2008.

Van den Broeke, M., Bamber, J., Ettema, J., Rignot, E., Schrama, E., van den Berg, W., van Meijgaard, E., Velicogna, I., and Wouters, B.: Partitioning Recent Greenland Mass Loss, Science, 326, 5955, 984-986, 2009.

Velicogna, I.: Increasing rates of ice mass loss from the Greenland and Antarctic ice sheets revealed by GRACE, Geophys. Res. Lett., 36, L19503, doi:10.1029/2009GL040222, 2009.

Voet, G. and Quadfasel, D.: Entrainment in the Denmark Strait overflow plume by mesoscale eddies, Ocean Sci., 6, 301-310, 2010 , http://www.ocean-sci.net/6/301/2010/.

Woodgate, R., Fahrbach, E., and Rohardt, G.: Structure and transport of the East Greenland Current at $75^{\circ} \mathrm{N}$ from moored current meters, J. Geophys. Res., 104, 18059-18072, 1999.

Yashayaev, I.: Hydrographic changes in the Labrador Sea, 1960 2005, Prog. Oceanogr., 73, 242-276, 2007. 